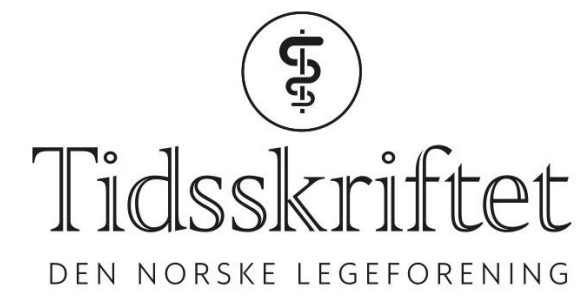

\title{
Kjønnsvariasjon, medisinsk behandling og vårt ansvar
}

DEBATT

\section{ANNE WAHRE}

E-post: uxwhra@ous-hf.no Anne Wæhre er ph.d., spesialist i barnesykdommer og overlege ved Nasjonal behandlingstjeneste for transseksualisme, barn og unge, Avdeling for barn og unges psykiske helse på sykehus (S-BUP), Barneog ungdomsklinikken, Oslo universitetssykehus, Rikshospitalet.

Forfatteren har fylt ut ICMJE-skjemaet og oppgir ingen interessekonflikter.

\section{MARTINA SCHORKOPF}

Martina Schorkopf er spesialist i barne- og ungdomspsykiatri og overlege ved Nasjonal behandlingstjeneste for transseksualisme, barn og unge, Avdeling for barn og unges psykiske helse på sykehus (S-BUP), Barne- og ungdomsklinikken, Oslo universitetssykehus, Rikshospitalet. Forfatteren har fylt ut ICMJE-skjemaet og oppgir ingen interessekonflikter.

Vi må sammen jobbe for et samfunn der barn og unge fritt kan uttrykke sin kjønnsidentitet. Som leger som jobber med barn og unge med kjønnsinkongruens, står vi ofte i etisk utfordrende situasjoner, ikke minst fordi vi mangler forskningsbasert kunnskap om kjønnsbekreftende behandling.

Vi vil rose Tidsskriftet som det siste året har tatt opp temaet kjønnsinkongruens (1). I denne artikkelen ønsker vi som treffer barn og unge som opplever kjønnsinkongruens, å dele våre erfaringer for å belyse noe av kompleksiteten knyttet til utredning og behandling.

I den nylig reviderte diagnosemanualen fra Verdens helseorganisasjon, ICD-11, er diagnosen transseksualisme borte. I stedet kommer diagnosen kjønnsinkongruens. Den medisinske diagnosen transseksualisme i ICD-1o beskriver en situasjon der en person opplever å ha en kjønnsidentitet som ikke samsvarer med det kjønn vedkommende ble tilskrevet ved fødsel, altså en opplevelse av å være enten gutt/mann eller jente/kvinne. En betingelse for å få diagnosen er at man opplever kjønnsdysfori, dvs. et uttalt ubehag ved at kjønn tildelt ved fødsel og egen opplevelse av kjønnsidentitet ikke stemmer overens.

I ICD-11 er diagnosen kjønnsinkongruens plassert i et nytt kapittel om seksuell helse, i motsetning til transseksualisme som var en psykiatrisk diagnose (1). I den nye diagnosen er ikke opplevelsen av kjønnsdysfori et krav, men personen må ha et sterkt ønske om å fjerne noen eller alle primære eller sekundære kjønnskarakteristika. Diagnosen åpner også for at kjønnsidentitet er flytende og inkluderer de med ikke-binær kjønnsidentitet, dvs. de som verken definerer seg som gutt/mann eller jente/kvinne. Diagnoseendringen forsterker behovet for skjerpet ivaretagelse av disse barna og ungdommene fra førstelinje til spesialisthelsetjenesten. 


\section{$\varnothing$ kning i henvisninger}

Både voksne og yngre personer med kjønnsinkongruens oppsøker i økende grad klinikker over hele verden (2-5). Årsaken er ukjent, men det spekuleres i om det kan bero på økt tilgang til behandling, økt kunnskap via internett, generelt økt åpenhet og oppmerksomhet i samfunnet for ulik kjønnsidentitet og kjønnsuttrykk, mindre stigmatisering eller at identitetsutviklingen i dag i større grad også innbefatter utforskning av kjønnsidentiteten (6).

Nasjonal behandlingstjeneste for transseksualisme for barn og unge (NBTS barn og unge) ved Oslo universitetssykehus tar imot alle som opplever kjønnsidentitetsutfordringer, kjønnsinkongruens og kjønnsdysfori, men tjenesten har tradisjonelt behandlet de som oppfyller diagnosen transseksualisme. De seneste årene har det vært en kraftig økning i antall henvisninger: På begynnelsen av 200o-tallet var det kun et fåtall barn og ungdom, mens vi i 2018 mottok godt over 200 henvisninger. Økningen utgjøres primært av tenåringer med kvinnelig kjønn tildelt ved fødsel. I 2017 utgjorde denne gruppen nærmere $70 \%$ av alle henvisninger, i 2012 ca. $35 \%$ (egne tall, ikke publisert).

Vår erfaring er at en stor andel av ungdommene har alvorlige psykiatriske symptomer. Dette kan være alvorlig depresjon, sosial fobi og angst, rusmisbruk, autismespektertilstand, selvskading, suicidale tanker og handlinger, psykotiske symptomer, spiseforstyrrelser eller en oppvekst der de har opplevd alvorlige traumer. Mange har også hatt kontakt med barnepsykiatrien tidligere for andre årsaker enn kjønnsinkongruens. Disse vanskene eller bekymringene kan være betydelige kilder til sterkt ubehag, og hvis de forblir ubehandlet, er det vår erfaring at de kan komplisere prosessen med å utforske kjønnsidentitet og finne løsninger for kjønnsinkongruens. Et tett samarbeid med lokal barne- og ungdomspsykiatrisk poliklinikk (BUP) er helt avgjørende for å sikre profesjonell ivaretagelse av barna og ungdommene parallelt med utredningen ved behandlingstjenesten. Vår kliniske erfaring er at ikke alle psykiske vansker hos denne gruppen nødvendigvis kan tilskrives kjønnsinkongruens. Dermed vil heller ikke alle plager løses med kjønnsbekreftende behandling. Det er ikke et argument mot kjønnsbekreftende behandling, men understreker behovet for en helhetlig trygg ivaretagelse.

\section{Manglende forskning}

Ny diagnose kan bety at flere vil søke seg til behandling. Forskning på kjønnsbekreftende behandling har så langt vært konsentrert om de som opplever kjønnsinkongruens i svært tidlig alder, og de som har fått diagnosen transseksualisme med et ønske om å leve som motsatt kjønn av det de fikk tildelt ved fødsel. Vi vet mye mindre om unge personer som opplever første tegn på kjønnsinkongruens i ungdomstiden, og langtidsdata foreligger ikke. Det er et stort behov for prospektive studier av den økende gruppen med tildelt kvinnelig kjønn ved fødsel og ungdommer med ikke-binær kjønnsidentitet.

Vi får henvisninger fra ungdommer som verken føler seg som gutt eller jente, som gutt og jente i ulik grad, og noen som ikke identifiserer seg med kjønn i det hele tatt. Det er økende oppmerksomhet i mediene og blant brukergrupper rundt det å anerkjenne individuelle forskjeller i kjønnsidentiteter og ulike behandlingsønsker. Helsepersonell blir dermed bedt om å støtte individuelle ønsker som kan inkludere medisinsk behandling. Som helsepersonell er vi forpliktet til først og fremst å ikke gjøre skade. Allerede i dag med den store økningen av ungdommer som søker seg til behandling, er dette svært aktuelt. Med ny diagnose blir dette satt ytterligere på prøve: Pasientgruppen er enda mer heterogen, og det er fravær av kliniske behandlingsprotokoller og evidensbasert forskning på pasienter med ikke-binær kjønnsidentitet. Hva vil være trygg behandling for hver enkelt? Hvor mye skal klinisk skjønn og pasientens egen kunnskap avgjøre hva som skal tilbys av behandling?

Samtidig vil vi understreke at vi har et felles ansvar for å jobbe for et samfunn der barn og ungdom med kjønnsvariasjon trygt kan få uttrykke seg, slik at de kan utvikle en trygg identitet med eller uten behov for medisinsk behandling. 
LITTERATUR:

1. Lie AK, Slagstad K. Diagnosens makt. Tidsskr Nor Legeforen 2018; 138. doi:10.4045/tidsskr.18.0438. [PubMed][CrossRef]

2. Aitken M, Steensma TD, Blanchard R et al. Evidence for an altered sex ratio in clinic-referred adolescents with gender dysphoria. J Sex Med 2015; 12: 756-63. [PubMed][CrossRef]

3. Wood H, Sasaki S, Bradley SJ et al. Patterns of referral to a gender identity service for children and adolescents (1976-2011): age, sex ratio, and sexual orientation. J Sex Marital Ther 2013;39:1-6. [PubMed][CrossRef]

4. Wiepjes CM, Nota NM, de Blok CJM et al. The Amsterdam Cohort of Gender Dysphoria Study (1972-2015): Trends in prevalence, treatment, and regrets. J Sex Med 2018; 15: 582-90. [PubMed][CrossRef]

5. Arcelus J, Bouman WP, Van Den Noortgate W et al. Systematic review and meta-analysis of prevalence studies in transsexualism. Eur Psychiatry 2015; 30: 807-15. [PubMed][CrossRef]

6. Kaltiala-Heino R, Bergman H, Työläjärvi M et al. Gender dysphoria in adolescence: current perspectives. Adolesc Health Med Ther 2018; 9:31-41. [PubMed][CrossRef]

Publisert: 8. april 2019. Tidsskr Nor Legeforen. DOI: 10.4045/tidsskr.19.0178

Mottatt 26.2.2019, godkjent 5·3.2019.

(C) Tidsskrift for Den norske legeforening 2020. Lastet ned fra tidsskriftet.no 